\title{
EVALUASI PENYIAPAN PROYEK KERJASAMA PEMERINTAH DENGAN BADAN USAHA (KPBU) KERETA API MAKASSAR- PAREPARE
}

\section{EVALUATION OF PUBLIC-PRIVATE PARTNERSHIP PREPARATION ON MAKASSAR-PAREPARE RAILWAY PROJECT}

\author{
Andi Syafirah Putri Abdi Patu ${ }^{1}$, Muhammad Heru Akhmadi \\ ${ }^{1,2}$ Politeknik Keuangan Negara STAN \\ Jl. Bintaro Utama Sektor V, Bintaro Jaya, Tangerang Selatan Banten, Indonesia \\ e-mail: heru.cio@gmail.com
}

Diserahkan: 11/07/2021; Diperbaiki: 09/09/2021; Disetujui: 28/09/2021

DOI: $10.47441 /$ jkp.v16i2.200

\begin{abstract}
Abstrak
Kerjasama Pemerintah dengan Badan Usaha (KPBU) merupakan suatu sistem pembiayaan proyek infrastruktur yang dikembangkan dalam rangka mengatasi keterbatasan anggaran pembangunan. Salah satu proyek strategis nasional yang menggunakan skema KPBU saat ini yaitu proyek KPBU Kereta Api (KA) MakassarParepare. Tulisan ini bertujuan untuk mengevaluasi tahap penyiapan proyek KPBU KA Makassar-Parepare. Metode penelitian yang digunakan adalah kualitatif deskriptif. Data primer dikumpulkan melalui proses wawancara, sedangkan data sekunder dikumpulkan melalui studi pustaka dan peraturan yang relevan dengan objek penelitian. Data yang diperoleh dianalisis dengan menggunakan aplikasi ATLAS.ti. Hasil penelitian menunjukkan bahwa penyiapan proyek KPBU KA MakassarParepare pada umumnya telah dilaksanakan sesuai dengan peraturan yang ada. Meski demikian, terdapat kendala dalam proses penyiapan seperti pada proses penetapan trase jalur kereta api yang mengalami kemunduran jadwal karena permasalahan pembebasan lahan, dan minimnya pemahaman penanggungjawab program kerjasama (PJPK) terhadap konsep KPBU. Hal ini terjadi karena proyek KA Makassar-Parepare merupakan proyek KPBU pertama yang ditangani oleh Kementerian Perhubungan selaku PJPK, sehingga kesiapan sumber daya manusia dan koordinasi organisasi yang baik sangat diperlukan dalam proses penyiapan proyek KPBU kereta api.
\end{abstract}

Kata Kunci: KPBU, Infrastruktur, Penyiapan Proyek.

\begin{abstract}
Public-Private Partnership (PPP) is an infrastructure project financing system developed to solve the limited development budget. The Makassar-Parepare railway is the first PPP project handled by the Ministry of Transportation as the PJPK. This paper aims to evaluate the preparation stage of the Makassar-Parepare project. The research method used is descriptive qualitative. Primary data was collected through interviews. The data obtained were analyzed using the ATLAS.ti application. The results of the study indicate that the PPP preparation of the Makassar-Parepare project has generally been well carried out based on regulations. However, there are some obstacles in the preparation process, such as schedule delays due to land acquisition and the lack of understanding of the person in charge of the cooperation program because of unpreparedness of human resources. Thus, good organizational coordination is needed in the preparation process of the PPP project.
\end{abstract}

Keywords: Public-Private Partnership, Infrastructure, Project Preparation 


\section{PENDAHULUAN}

Permasalahan ketimpangan pertumbuhan dan pembangunan antar wilayah bukanlah masalah baru lagi bagi pemerintah, khususnya terkait ketimpangan pertumbuhan antara Jawa dan pulau lainnya di Indonesia. Hal ini salah satunya disebabkan oleh terjadinya perbedaan pembangunan infrastruktur di beberapa wilayah di Indonesia. Tak dapat dipungkiri, infrastruktur memang memainkan peranan yang sangat penting dalam pertumbuhan ekonomi. Dengan adanya infrastruktur, akses antar wilayah dapat menjadi lebih mudah dan aktivitas ekonomi juga dapat lebih ditingkatkan. Peningkatan aktivitas ekonomi akan secara langsung berdampak pada pertumbuhan ekonomi di Indonesia, sehingga dapat dikatakan pertumbuhan ekonomi dan infrastruktur sebenarnya merupakan dua hal yang tidak dapat dipisahkan dan saling bergantung satu sama lain (Sukwika 2018). Hal ini sejalan dengan hasil penelitian yang dilakukan oleh Sumardjoko dan Akhmadi (2019) yang menyatakan bahwa penyediaan infrastruktur berpengaruh positif terhadap pertumbuhan ekonomi wilayah dan penurunan kemiskinan, karena dapat mendorong pertumbuhan ekonomi hingga $0.045 \%$ dengan adanya peningkatan kapasitas listrik sekitar $1 \%$. Adapun peningkatan aktivitas ekonomi yang ada dinilai akan berimplikasi terhadap penurunan kemiskinan, berupa kenaikan $1 \%$ pertumbuhan ekonomi yang diestimasikan dapat menurunkan tingkat kemiskinan sebanyak 1,1\%.

Berdasarkan laporan Indeks Kompetisi Global 2019 (Global Competitiveness Report), Indeks Kualitas Infrastruktur Indonesia mengalami penurunan peringkat dari yang sebelumnya peringkat 71 pada tahun 2018 menjadi peringkat 72 pada tahun 2019, sehingga membuat Indonesia masih harus berada di bawah negara-negara ASEAN lainnya, seperti Singapura, Malaysia, dan Thailand. Hal ini mendorong pemerintah untuk menetapkan target berupa pencapaian rata-rata pertumbuhan GDP sebesar $6 \%$ dan pengalokasian Rp6.445 triliun atau 6,2\% dari GDP untuk belanja infrastruktur. Namun demikian, anggaran yang tersedia ternyata hanya bisa mendanai sebesar Rp2.385 triliun atau 37\% dari total kebutuhan investasi. Akibatnya, pemerintah pun harus menghadapi permasalahan selisih pendanaan (financing gap) yang mengharuskan pemerintah untuk memikirkan alternatif pembiayaan yang bisa digunakan untuk terus mendorong pembangunan infrastruktur secara merata di Indonesia. Salah satu bentuk alternatif pembiayaan yang diperkenalkan yaitu skema pembiayaan kerjasama pemerintah dan badan usaha atau biasa disingkat dengan istilah KPBU. KPBU inilah yang saat ini sedang ditingkatkan penerapannya untuk mengatasi keterbatasan kemampuan APBN dalam mendanai pembangunan infrastruktur, termasuk untuk mendorong partisipasi swasta (PPP Book 2020).

Sejauh ini, ada banyak proyek infrastruktur pemerintah yang telah direncanakan untuk dibangun dengan skema KPBU. Jumlah proyek-proyek infrastruktur yang dibiayai dengan skema KPBU ini juga kemungkinan besar akan terus meningkat setiap tahunnya. Hal ini ditandai dengan telah disusunnya rencana daftar proyek infrastruktur yang akan dilaksanakan dengan skema KPBU pada tahun 2021 oleh pemerintah. (Fadli 2020) Penyusunan rencana proyek infrastruktur dengan skema KPBU tersebut secara langsung membuktikan bahwa skema pembiayaan KPBU akan terus berpotensi untuk lebih dikembangkan lagi dalam pembangunan proyek-proyek infrastruktur pemerintah lainnya di masa yang akan datang. Pelaksanaan pembangunan proyek dengan skema KPBU ini sebenarnya bukanlah hal yang mudah untuk dilakukan, karena Penanggung Jawab Program Kerjasama (PJPK) perlu melakukan berbagai tahap skema KPBU yang terdiri atas tahap perencanaan, penyiapan, transaksi dan pelaksanaan. Diantara keempat tahapan tersebut, penelitian ini akan memfokuskan pada tahap penyiapan proyek yang telah selesai dilaksanakan pada saat proses pengumpulan data proyek KPBU Kereta Api (KA) Makassar-Parepare.

Ruang lingkup penelitian ini meliputi tahapan penyiapan KPBU pada proyek infrastruktur berupa proyek KA Makassar-Parepare yang berlokasi di Provinsi Sulawesi 
Selatan. Proyek KA Makassar-Parepare terbagi atas segmen jalur kereta api, mulai dari segmen A, B, C, D, E dan F yang mencakup Kota Makassar, Kabupaten Maros, Pangkep, Barru dan Kota Parepare. Berdasarkan informasi dari Direktorat Jenderal Perkeretaapian (DJKA) Kementerian Perhubungan, ruang lingkup proyek KA yang dibiayai melalui skema KPBU ini meliputi konstruksi, pengoperasian, dan perawatan segmen F oleh Badan Usaha Pelaksana (BUP).

Pelaksanaan tahap penyiapan proyek KPBU dapat dikatakan cukup kompleks, karena mencakup penyusunan beberapa dokumen penting proyek seperti pra studi kelayakan yang meliputi berbagai aspek dari proyek, Analisis Mengenai Dampak Lingkungan (AMDAL), Rencana Anggaran Belanja (RAB) hingga Kerangka Acuan Kerja (KAK) proyek. Termasuk juga kegiatan-kegiatan penyiapan lainnya mulai dari penetapan lokasi proyek, pelaksanaan konsultasi publik dan penjajakan minat pasar, penetapan skema pengembalian investasi, hingga pengajuan dukungan pemerintah. Oleh karena itu, penelitian ini disusun untuk mengkaji lebih lanjut mengenai hal-hal yang dilakukan oleh Kementerian Perhubungan selaku PJPK selama tahap penyiapan dan juga hasil yang perlu diperoleh dalam rangka memahami keseluruhan pelaksanaan penyiapan suatu proyek KPBU. Hal-hal yang perlu dievaluasi selama proses penyiapan proyek KPBU ini juga turut menjadi tujuan penulisan artikel ini, terlebih karena proyek KPBU KA Makassar-Parepare termasuk proyek KPBU pertama yang dilaksanakan di Kementerian Perhubungan. Hal ini dilakukan dengan harapan agar dapat menjadi bahan perbaikan, baik bagi PJPK, maupun pemerintah dalam mempersiapkan proyek-proyek KPBU lainnya di masa yang akan datang, sehingga masalah ataupun kendala yang ditemukan dapat diatasi dengan solusi dan strategi yang lebih baik.

\section{METODE PENELITIAN}

Metode penelitian yang digunakan adalah metode kualitatif deskriptif. Data primer diambil melalui wawancara dengan informan yang ditentukan secara purposive. Informan berasal dari Direktorat Lalu Lintas dan Angkutan Kereta Api (DJKA) Kementerian Perhubungan, serta Direktorat Pengelolaan Dukungan Pemerintah dan Pembiayaan Infrastruktur (Direktorat PDPPI) Kementerian Keuangan. Data sekunder yang digunakan adalah berbagai peraturan perundang-undangan dan referensi yang relevan dengan penerapan skema KPBU. Analisis data menggunakan aplikasi software ATLAS.ti, yaitu alat bantu proses analisis data kualitatif, yang membantu dalam mengorganisasikan dan menganalisis data hasil wawancara yang diperoleh secara lebih efektif, efisien, dan teratur (Afriansyah 2018). Penelitian ini juga menggunakan studi literatur melalui pemanfaatan digital repositori, sehingga dapat memperkuat analisis hasil penelitian dan meningkatkan kualitas penelitian bidang keuangan (Akhmadi 2017).

\section{HASIL DAN PEMBAHASAN}

\section{Tahapan Penyiapan Proyek KPBU Kereta Api Makassar-Parepare}

Tahapan penyiapan proyek KPBU merupakan tahapan lanjutan dari tahap sebelumnya yaitu perencanaan KPBU. Output yang dihasilkan pada tahap perencanaan adalah kajian yang mencakup analisis kebutuhan (need analysis), kriteria kepatuhan (compliance criteria), faktor penentu nilai manfaat uang (value for money), analisa potensi pendapatan dan skema pembiayaan proyek, serta rekomendasi dan rencana tindak lanjut (Maulana 2021). Adapun pelaksanaan KPBU proyek KA Makassar-Parepare dilakukan dengan mengacu kepada Peraturan Menteri Perencanan Pembangunan Nasional (PPN) Nomor 4 Tahun 2015 tentang Tata Cara Pelaksanaan Kerjasama Pemerintah dengan Badan Usaha dalam Penyediaan Infrastruktur yang saat ini telah mengalami perubahan menjadi Peraturan menteri PPN Nomor 2 Tahun 2020. 


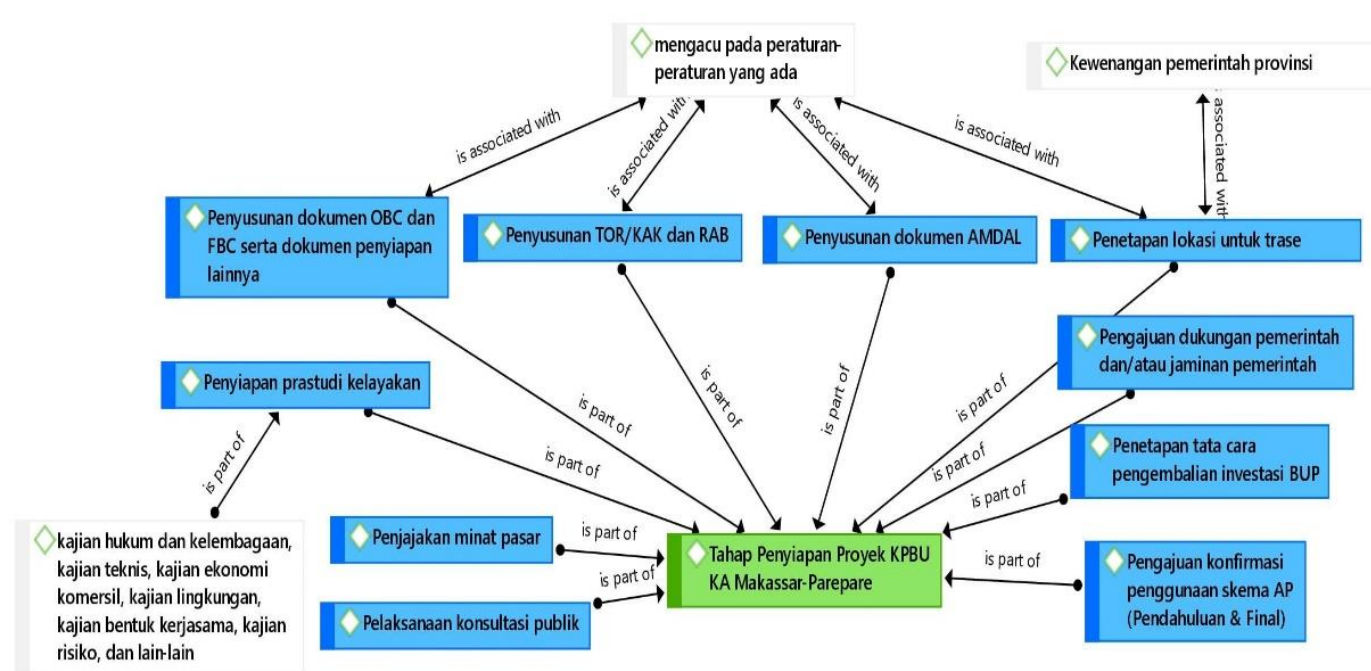

Gambar 1. Analisis Hasil Wawancara (Networking View) 1

(Sumber: data primer yang diolah)

Berdasarkan gambar 1, tahap penyiapan proyek KPBU KA Makassar-Parepare meliputi kegiatan penyiapan dan penyusunan dokumen kajian prastudi kelayakan awal dan akhir, penyusunan dokumen $\mathrm{KAK}$ dan $\mathrm{RAB}$, penetapan lokasi untuk trase, penyusunan kajian lingkungan/dokumen AMDAL, pelaksanaan konsultasi publik dan penjajakan minat pasar (market sounding), hingga pengajuan permohonan bantuan dukungan dan jaminan pemerintah serta penentuan skema pengembalian investasi Badan Usaha Pelaksana (BUP), termasuk pengajuan konfirmasi penggunaan skema pembayaran ketersediaan layanan atau Availability Payment (AP) untuk proyek KPBU yang bersangkutan.

Berdasarkan Peraturan Menteri Keuangan (PMK) Nomor 260 Tahun 2016, sebagai proyek yang menggunakan skema AP, PJPK proyek KPBU KA Makassar-Parepare perlu melakukan penyusunan rancangan perjanjian kerjasama dan surat komitmen pelaksanaan pembayaran ketersediaan layanan. Dalam pelaksanaan penyiapan skema AP tersebut, PJPK juga akan memperoleh surat konfirmasi final untuk penggunaan skema AP, apabila dinilai telah memenuhi berbagai persyaratan perolehan konfirmasi final yang ditetapkan. Pada tahap ini PJPK juga perlu memastikan bahwa anggaran yang dibutuhkan untuk keseluruhan tahap penyiapan proyek dapat tersedia secara memadai.

\section{Penyusunan Dokumen Pra-Studi Kelayakan}

Dokumen pra-studi kelayakan merupakan dokumen yang berisi kajian yang disusun oleh PJPK dalam rangka menilai kelayakan KPBU. Penyusunan dokumen pra-studi kelayakan dimungkinkan untuk dilakukan sebanyak dua kali, yang terdiri atas Prastudi Kelayakan Awal (Outline Business Case/OBC) dan Prastudi Kelayakan Akhir (Final Business Case/FBC). Prastudi kelayakan akhir dapat dikatakan sebagai bentuk pendetailan atau penyempurnaan pra-studi kelayakan awal, karena dalam pra-studi kelayakan akhir ini, substansi data yang digunakan jauh lebih rinci dibandingkan kajian pra-studi kelayakan awal. Akibatnya, hal ini memungkinkan adanya perbedaan hasil pada dokumen OBC dan FBC yang disusun oleh PJPK.

Kajian awal pra-studi kelayakan meliputi beberapa bentuk kajian, antara lain kajian hukum dan kelembagaan, teknis, ekonomi dan komersial, lingkungan dan sosial, bentuk kerjasama dalam penyediaan infrastruktur, risiko, kebutuhan dukungan pemerintah dan/atau jaminan pemerintah, serta kajian mengenai hal-hal yang perlu ditindaklanjuti (Maulana 2021). Sementara itu, kajian akhir pra-studi kelayakan secara umum meliputi kajian yang sama, namun hanya perlu dilakukan oleh PJPK apabila memang dinilai perlu adanya penyesuaian data dengan situasi dan kondisi terkini termasuk pemutakhiran atas layak atau tidaknya proyek KPBU serta siap atau tidaknya proyek untuk dijalankan. 
Penyelesaian dokumen pra-studi kelayakan proyek KPBU KA Makassar-Parepare telah disusun secara lengkap dan komprehensif oleh Kementerian Perhubungan selaku PJPK dengan berpedoman pada Peraturan Pemerintah Nomor 38 Tahun 2015. Dalam rangka melengkapi penyelesaian dokumen prastudi kelayakan awal, Kementerian Perhubungan juga telah menyusun dan melengkapi dokumen FBC untuk menyempurnakan dokumen OBC.

\section{Penyusunan Kerangka Acuan Kerja (KAK) dan Rencana Aanggaran Biaya (RAB)}

Penyusunan KAK dan RAB merupakan kegiatan yang harus dilakukan oleh PJPK dalam rangka pelaksanaan proyek KPBU. KAK berisi gambaran mengenai perencanaan proyek mulai dari latar belakang, tujuan, ruang lingkup proyek, dan hal-hal terkait lainnya yang telah disepakati untuk mengarahkan pelaksanaan proyek sesuai dengan target yang telah ditetapkan (Rahmah 2019). Sedangkan RAB merupakan dokumen perencanaan proyek yang berisi perkiraan besaran biaya yang mungkin akan dikeluarkan selama masa pelaksanaan proyek. RAB memuat uraian pekerjaan, volume pekerjaan dan satuannya, Harga Satuan Pekerjaan (HSP), dan jumlah harga pekerjaan.

Tanpa dokumen KAK dan RAB, pelaksanaan proyek tentunya bisa menjadi tidak terarah atau bahkan mengakibatkan timbulnya pembengkakan biaya, karena tidak adanya perencanaan yang baik. KAK juga dapat mengurangi risiko keterlambatan proyek (Nenny 2017). Oleh karena itu, dokumen KAK dan RAB sangat penting untuk disusun, agar proyek dapat terlaksana sesuai target yang diharapkan (Rahmah 2019). Penentuan RAB proyek KA Makassar-Parepare mengikuti standar biaya di lingkungan Kementerian Perhubungan sesuai Peratuan Menteri Perhubungan Nomor 78 Tahun 2014 dan standar harga satuan Pemerintah Provinsi Sulawesi Selatan.

\section{Penetapan Lokasi untuk Trase Jalur Kereta Api}

Trase merupakan rencana jalur kereta api, yang juga perlu dilakukan penetapan lokasinya pada tahap penyiapan proyek KPBU. Menurut Pasal 115 ayat 2 Peraturan Pemerintah Nomor 56 Tahun 2009, trase jalur KA memuat paling sedikit titik-titik koordinat, titik stasiun, proyeksi kebutuhan lahan dan skala gambar. Adapun rencana jalur KA Makassar-Parepare telah disusun oleh PJPK sesuai dengan PP Nomor 56 Tahun 2009. Seluruh jalur kereta, stasiun dan fasilitas kereta yang telah direncanakan untuk dibangun pada titik-titik tertentu akan dituangkan dalam rencana jalur KA atau trase ini.

Pembangunan jalur KA Makassar-Parepare merupakan bagian dari pengembangan transportasi di Provinsi Sulawesi Selatan, yang masuk dalam koridor barat. Dari total kebutuhan trase kereta api 1.533,1 km, panjang trase Makassar-Parepare-Pinrang sebesar $15,56 \%$ atau $238,5 \mathrm{~km}$. Selanjutnya pada koridor ini akan dibangun sebanyak 25 stasiun (A.S 2014). Menurut DJKA, jalur KA Makassar-Parepare yang akan dibangun meliputi kota Makassar, kabupaten Maros, Pangkep, Barru, dan kota Parepare.

\section{Penyusunan Dokumen AMDAL}

AMDAL adalah metode analisis yang dikembangkan oleh Kementerian Lingkungan Hidup dan beberapa universitas di Indonesia dalam rangka membandingkan dan mengevaluasi manfaat pembangunan infrastruktur dan dampaknya terhadap lingkungan (biaya Rencana Pengelolaan Lingkungan Hidup atau RKL dan biaya Rencana Pemantauan Lingkungan Hidup atau RPL) (Razif 2018). Penyusunan dokumen AMDAL ini telah dilakukan oleh Kementerian Perhubungan selaku PJPK dengan mengacu pada dokumen-dokumen yang telah dipersiapkan sebelumnya, antara lain dokumen persyaratan penetapan trase, dokumen perencanaan pengadaan tanah, serta dokumen-dokumen terkait lainnya. 


\section{Pelaksanaan Konsultasi Publik}

Sebagaimana proyek-proyek KPBU lainnya, proyek KA Makassar-Parepare juga melakukan kegiatan konsultasi publik di Provinsi Sulawesi Selatan yang melibatkan pihakpihak stakeholder terkait, khususnya masyarakat terdampak. Berbagai masukan dari masyarakat yang disampaikan baik secara tertulis maupun lisan melalui kegiatan konsultasi publik ini turut menjadi pertimbangan dalam melakukan evaluasi lebih lanjut terkait pelaksanaan proyek KA Makassar-Parepare. Menurut DJKA, masyarakat Sulawesi Selatan secara umum menunjukkan antusiasme yang tinggi atas rencana pembangunan jalur KA Makassar-Parepare ini. Hal ini dikarenakan proyek KA Makassar-Parepare akan menjadi sarana transportasi kereta api pertama yang ada di Pulau Sulawesi, sehingga mereka tentunya berharap agar proyek ini dapat segera terwujud.

\section{Pelaksanaan Penjajakan Minat Pasar}

Penjajakan minat pasar ini dilakukan dalam rangka memberitahukan calon investor terkait proyek infrastruktur yang direncanakan, sekaligus memperoleh masukan atas skema kerjasama yang ditawarkan oleh pemerintah. Penjajakan minat pasar juga bertujuan untuk mengurangi risiko perubahan kondisi pasar (Maharani et al. 2016). Dalam pelaksanaannya, Kementerian Perhubungan selaku PJPK memberikan penjelasan dan gambaran terkait rencana proyek kepada calon-calon investor. Kemudian dilanjutkan dengan sesi tanya jawab dan one-on-one meeting antara calon investor bersama PJPK yang dibagi menjadi beberapa tim. Melalui one-on-one meeting inilah, calon investor yang berasal dari dalam dan luar negeri dapat hadir menanyakan banyak hal terkait rencana proyek yang akan dilaksanakan.

\section{Penentuan Skema Pengembalian Investasi Badan Usaha Pelaksana (BUP)}

Kementerian Perhubungan selaku PJPK telah memutuskan bahwa skema pengembalian investasi yang paling tepat untuk proyek KPBU KA Makassar-Parepare adalah skema AP. Keputusan ini didasarkan atas pertimbangan bahwa proyek KA Makassar-Parepare merupakan proyek kereta api pertama yang akan dibangun di Provinsi Sulawesi Selatan, sehingga pola transportasi di tahun-tahun awal operasi berpotensi menyebabkan ketidakpastian permintaan yang dapat menyebabkan ketidakpastian pengembalian investasi dari BUP apabila hanya mengandalkan perolehan dari skema pembayaran pengguna (end-user). Dengan penerapan skema AP ini, BUP akan melakukan kegiatan desain, konstruksi, operasi, dan pemeliharaan fasilitas proyek kereta api selama masa kerjasama dan kemudian menyerahkannya kembali kepada pemerintah apabila jangka waktu kerjasama telah berakhir (Wibowo dan Senjaya 2020).

Skema AP ini dinilai sebagai skema pengembalian investasi yang menguntungkan bagi kedua pihak, baik pemerintah maupun badan usaha. Dengan diterapkannya skema AP, risiko permintaan tidak perlu lagi ditanggung oleh BUP, dan kepastian terhadap tingkat pengembalian investasi oleh BUP juga dapat lebih meningkat. Pemerintah juga tidak perlu lagi mengeluarkan belanja modal dalam jumlah penuh untuk kegiatan pembangunan proyek, karena biaya tersebut akan menjadi tanggungan BUP. Meski demikian, biaya yang wajib ditanggung oleh pemerintah dalam rangka membayarkan AP setiap tahun kepada BUP juga tidaklah sedikit, sehingga membutuhkan perencanaan anggaran yang baik di awal. Hal inilah yang menjadi alasan mengapa PJPK perlu melakukan analisis biaya manfaat (cost-benefit analysis) pada kajian prastudi kelayakannya terlebih dahulu, yaitu untuk memastikan bahwa manfaat pembangunan proyek setidaknya mampu menutupi/mengompensasi biaya AP yang dibayarkan kepada BUP (Wibowo dan Senjaya 2020). Biaya manfaat untuk proyek KA Makassar-Parepare ini telah dihitung oleh Kementerian Perhubungan selaku PJPK dan diserahkan sebagai dasar usulan penggunaan skema KPBU. 


\section{Pengajuan Bantuan Dukungan Pemerintah dan/atau Jaminan Pemerintah}

Permohonan pemberian dukungan pemerintah diajukan oleh PJPK kepada Kementerian Keuangan dengan memperhatikan setiap persyaratan kualifikasi dan kelengkapan dokumen termasuk ketentuan mengenai mekanisme/alur pengajuan dukungan pemerintah sesuai regulasi yang ditetapkan. Permohonan yang diajukan tentunya tidak dapat diterima begitu saja oleh Kementerian Keuangan, namun terlebih dahulu perlu dilakukan evaluasi berdasarkan aspek-aspek tertentu untuk mengidentifikasi layak atau tidaknya proyek KPBU yang bersangkutan menerima dukungan pemerintah yang diusulkan. Adapun usulan jaminan pemerintah berupa penjaminan infrastruktur diajukan oleh PJPK kepada Badan Usaha Penjaminan Infrastruktur (BUPI), disertai dengan ketentuan-ketentuan pengajuan penjaminan dan akan dievaluasi lebih lanjut pula oleh BUPI. Melalui proses pengajuan bantuan dukungan dan penjaminan ini, Kementerian Perhubungan selaku PJPK berhasil memperoleh dukungan pemerintah berupa fasilitas penyiapan proyek dan pendampingan transaksi dari Kementerian Keuangan serta penjaminan infrastruktur dari PT Penjaminan Infrastruktur Indonesia (PT PII).

\section{Pengajuan Konfirmasi Penggunaan Skema Availability Payment (AP)}

Skema AP merupakan skema pengembalian investasi yang dilakukan melalui pembayaran oleh PJPK kepada BUP secara berkala selama masa operasi proyek dengan mengacu pada kualitas dan kriteria yang disepakati dalam Perjanjian Kerjasama (PKS). PJPK perlu mengajukan konfirmasi kepada Kementerian Keuangan yaitu Direktorat Jenderal Pengelolaan Pembiayaan Dan Risiko (DJPPR) melalui Direktorat Pengelolaan Dukungan Pemerintah dan Pembiayaan Infrastruktur (Direktorat PDPPI) mengenai pelaksanaan proyek KPBU dengan skema pembayaran AP. Konfirmasi penggunaan skema pembayaran ketersediaan layanan ini terdiri atas surat konfirmasi pendahuluan dan surat konfirmasi final. Surat konfirmasi pendahuluan diterbitkan oleh Direktorat PDPPI sebelum tahap penyiapan dimulai, sedangkan surat konfirmasi final diterbitkan sebelum PJPK menerbitkan dokumen permintaan proposal (request for proposal) untuk pengadaan BUP pada tahap penyiapan. Adapun surat konfirmasi final ini akan segera diterbitkan oleh Direktorat PDPPI apabila PJPK telah selesai memenuhi segala ketentuan dan persyaratan yang telah ditetapkan.

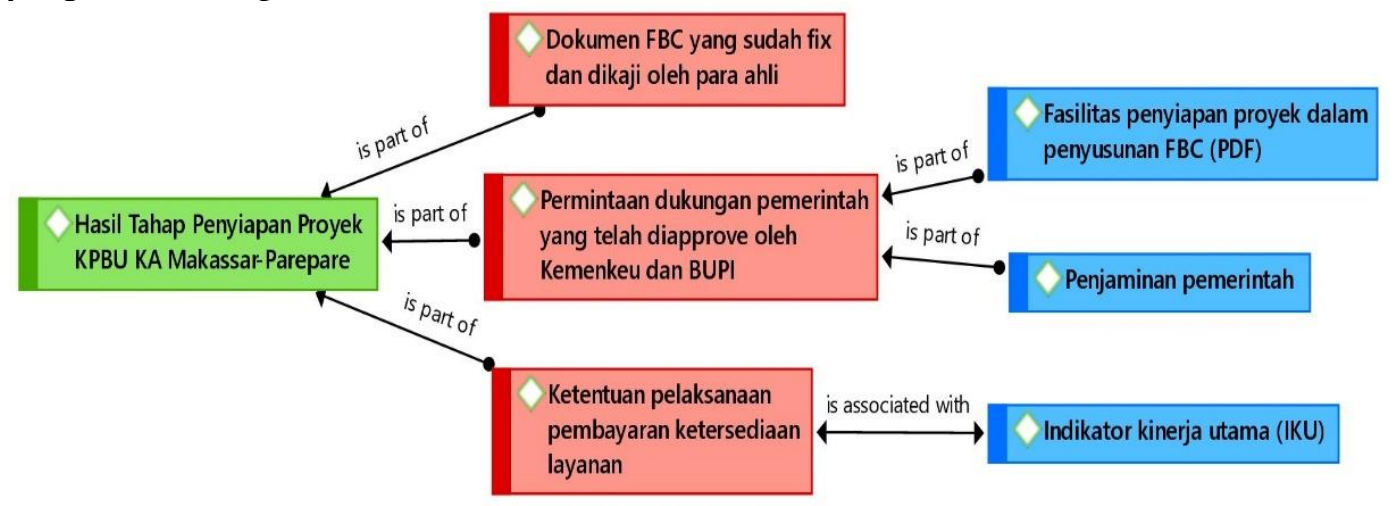

Gambar 2. Analisis Hasil Wawancara (Networking view) 2 (Sumber: data primer yang diolah)

Sesuai dengan gambar 2, pelaksanaan tahap penyiapan proyek KPBU KA Makassar-Parepare memperoleh hasil berupa dokumen kajian prastudi kelayakan akhir atau dokumen FBC yang sudah dikaji oleh ahli, permintaan dukungan dan penjaminan yang telah disetujui oleh Kementerian Keuangan dan BUPI, serta ketentuan pelaksanaan pembayaran ketersediaan layanan yang telah disepakati dalam rancangan PKS, dan surat konfirmasi final penggunaan skema AP. Adapun fasilitas penyiapan proyek dalam penyusunan dokumen OBC dan jaminan infrastruktur merupakan bagian dari bentuk 
persetujuan Kementerian Keuangan dan BUPI atas permohonan pemberian dukungan dan penjaminan pemerintah. Sementara itu, Indikator Kinerja Utama (IKU) yang termuat dalam perjanjian kerjasama AP berhubungan dengan ketentuan pelaksanaan AP, karena akan menjadi dasar dalam pemberian besaran AP yang telah disepakati kepada BUP.

\section{Bentuk Dukungan Pemerintah dalam Pelaksanaan Proyek KPBU KA Makassar- Parepare}

Pemerintah ikut terlibat dengan memberikan pengawasan dan dukungan atas kinerja badan usaha maupun PJPK melalui pemberian dukungan dan/atau jaminan proyek. Adapun bentuk dukungan yang dapat dilihat pada pelaksanaan proyek KPBU KA Makassar-Parepare ini yaitu berupa fasilitas penyiapan proyek (Project Development Facility/ PDF), penjaminan infrastruktur, dan pengembalian investasi dalam bentuk AP.

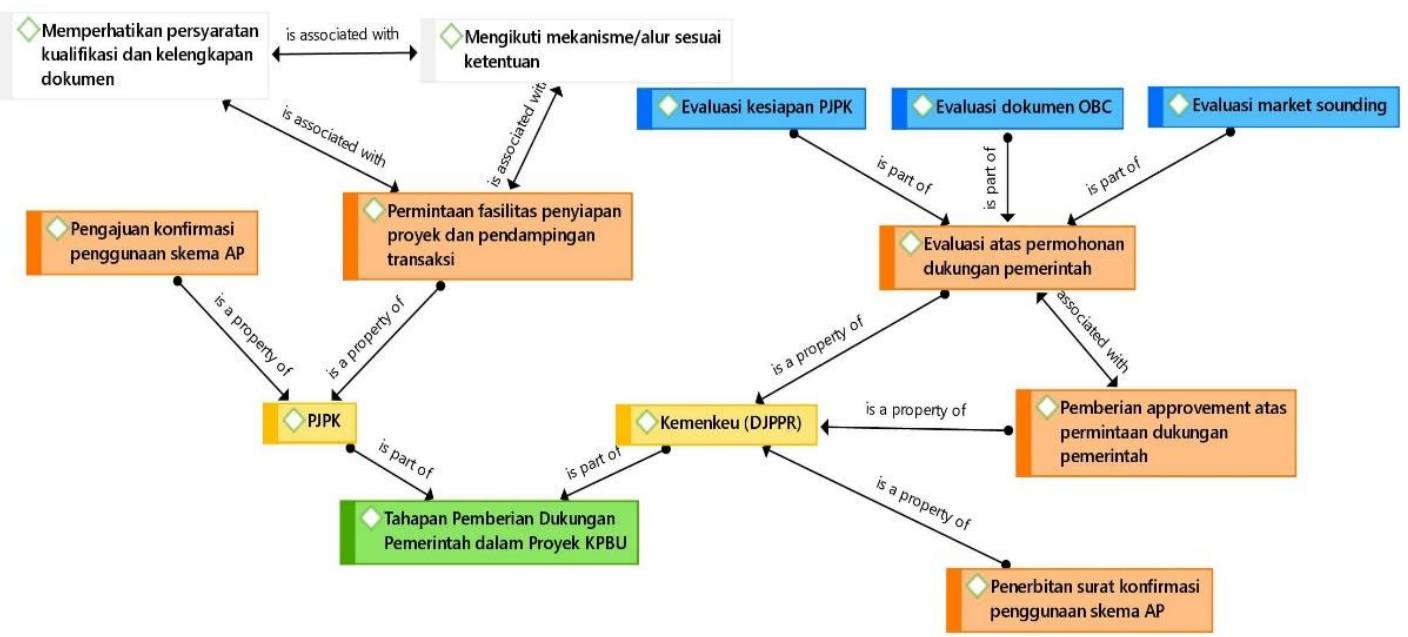

Gambar 3. Analisis Hasil Wawancara (Networking View) 3

(Sumber: data primer yang diolah)

Menurut hasil analisis wawancara pada gambar 3, pada proses pemberian dukungan pemerintah, PJPK mengajukan permohonan fasilitas penyiapan proyek dan pendampingan transaksi, serta konfirmasi penggunaan skema pembayaran ketersediaan layanan kepada Kementerian Keuangan atau Direktorat PDPPI. Adapun Direktorat PDPPI sebagai wakil Kementerian Keuangan berperan dalam melakukan evaluasi dan memberikan persetujuan atas permohonan PDF yang diajukan oleh Kementerian Perhubungan selaku PJPK, termasuk menerbitkan surat konfirmasi mengenai penggunaan skema AP, baik itu berupa surat konfirmasi pendahuluan maupun final.

\section{Fasilitas Penyiapan Proyek/Project Development Facility (PDF)}

Dukungan berupa PDF diberikan oleh Kementerian Keuangan pada tahap penyiapan proyek KPBU. PDF ini diberikan dengan tujuan untuk membantu PJPK dalam proses penyiapan proyek dan dapat dimanfaatkan oleh PJPK hingga proyek mencapai tahap pemenuhan pembiayaan (Suhendra 2017). Ketentuan mengenai fasilitas penyiapan proyek diatur dalam PMK Nomor 265/PMK.08/2015 tentang Fasilitas Dalam Rangka Penyiapan dan Pelaksanaan Transaksi Proyek Kerjasama Pemerintah dan Badan Usaha dalam Penyediaan Infrastruktur, yang kemudian mengalami perubahan menjadi PMK Nomor 73/PMK.08/2018 dan PMK Nomor 180/PMK.08/2020.

Menurut DJPPR, hal-hal yang perlu dilakukan DJPPR dalam pemberian dukungan pemerintah meliputi penyusunan rencana/identifikasi terkait proyek yang akan diberikan dukungan, pelaksanaan evaluasi atas permohonan dukungan, serta penyampaian rekomendasi kepada Menteri Keuangan terkait pemberian dukungan pemerintah berdasarkan hasil evaluasi yang dilakukan. Evaluasi atas permohonan pemberian dukungan 
pemerintah saat ini sebenarnya sedikit berbeda dibandingkan dengan evaluasi atas proyek KPBU KA Makassar-Parepare dulu, karena peraturan untuk fasilitas penyiapan ini sendiri sudah mengalami perubahan sebanyak dua kali sejak tahun 2015 lalu, yaitu pada tahun 2018 dan 2020. Ada beberapa aspek yang dievaluasi dari pengajuan permohonan PDF proyek KPBU KA Makassar-Parepare, antara lain evaluasi atas kesiapan PJPK, evaluasi dokumen OBC dan evaluasi penjajakan minat pasar.

Berdasarkan hasil wawancara bersama DJPPR, pemberian PDF kepada PJPK secara umum terbagi atas beberapa metode, antara lain PDF yang diberikan langsung oleh Kementerian Keuangan dengan cara menyewa konsultan. PDF yang diberikan melalui kerjasama dengan lembaga internasional seperti JAICA dan ADB. PDF yang diberikan melalui penugasan kepada BUMN. Khusus untuk proyek KPBU KA Makassar-Parepare ini, dukungan PDF diberikan melalui penugasan kepada BUMN di bawah Kementerian Keuangan, yaitu PT Penjaminan Infrastruktur Indonesia (PT PII).

Setelah melalui tahap evaluasi dan memperoleh konfirmasi persetujuan dari Kementerian Keuangan, proses pemberian PDF akan dilanjutkan dengan pembuatan perjanjian/kesepakatan induk bersama PJPK. Apabila perjanjian telah selesai dibuat, Kementerian Keuangan akan segera menerbitkan KMK penugasan kepada BUMN yang ditunjuk yaitu PT PII, dengan terlebih dahulu melalui serangkaian evaluasi, termasuk penyusunan perjanjian penugasan yang mencakup kewajiban dan tugas PT PII, serta biaya dan kompensasi yang akan diberikan kepada PT PII sebagai BUMN. Secara teknis, hal ini memang akan menghubungkan PT PII dan PJPK secara langsung, namun demikian, tidak menghilangkan peran Kementerian Keuangan dalam pelaksanaan penyiapan proyek itu sendiri, karena Kementerian Keuangan akan tetap melakukan evaluasi dan monitoring secara rutin atas output yang dihasilkan, termasuk memberikan masukan dan bantuan jika memang diperlukan.

Bentuk fasilitas pendampingan penyiapan proyek yang diberikan kepada PJPK melalui PDF ini adalah pendampingan dalam penyusunan kajian akhir, termasuk kajian/dokumen pendukung maupun pendampingan dalam proses pengajuan dukungan pemerintah seperti penjaminan infrastruktur atau dukungan kelayakan, jika memang diperlukan. Pendanaan pemberian PDF dapat bersumber dari APBN atau sumber lainnya yang sah. Adapun untuk PDF proyek KPBU KA Makassar-Parepare ini, Kementerian Keuangan menggunakan anggaran APBN BA BUN, yaitu BA BUN 999 atau alokasi khusus.

\section{Penjaminan Infrastruktur}

Berdasarkan analisis hasil wawancara (gambar 4), pemberian penjaminan infrastruktur pada proyek KPBU dilakukan dengan tujuan untuk meningkatkan kelayakan kredit (credit-worthiness) proyek infrastruktur dan menarik investor/lender agar ingin terlibat dalam proyek KPBU yang direncanakan. Penjaminan oleh pemerintah ini dikategorikan sebagai dukungan kontijen, karena pemenuhan kewajiban pembayaran jaminan oleh pemerintah kepada pihak yang dijamin tergantung pada terjadi atau tidaknya suatu kejadian yang dijamin (Irwin 2007). Penjaminan infrastruktur diberikan berdasarkan tingkat kecukupan modal BUPI yang bersangkutan. Jika dalam suatu kondisi biaya penjaminan yang diperlukan ternyata melampaui modal BUPI, Kementerian Keuangan akan melakukan kegiatan penjaminan bersama melalui pembagian risiko yang adil antara kedua pihak. Meski demikian, tugas penjaminan yang diserahkan kepada BUPI ini akan senantiasa diusahakan untuk tidak melampaui kemampuan modal BUPI, sehingga proses penjaminan juga dapat dilaksanakan dengan efisien dan tepat sasaran. Ketentuan mengenai penjaminan infrastruktur diatur secara khusus dalam Peraturan Pemerintah Nomor 78 Tahun 2010 tentang Penjaminan Infrastruktur. 


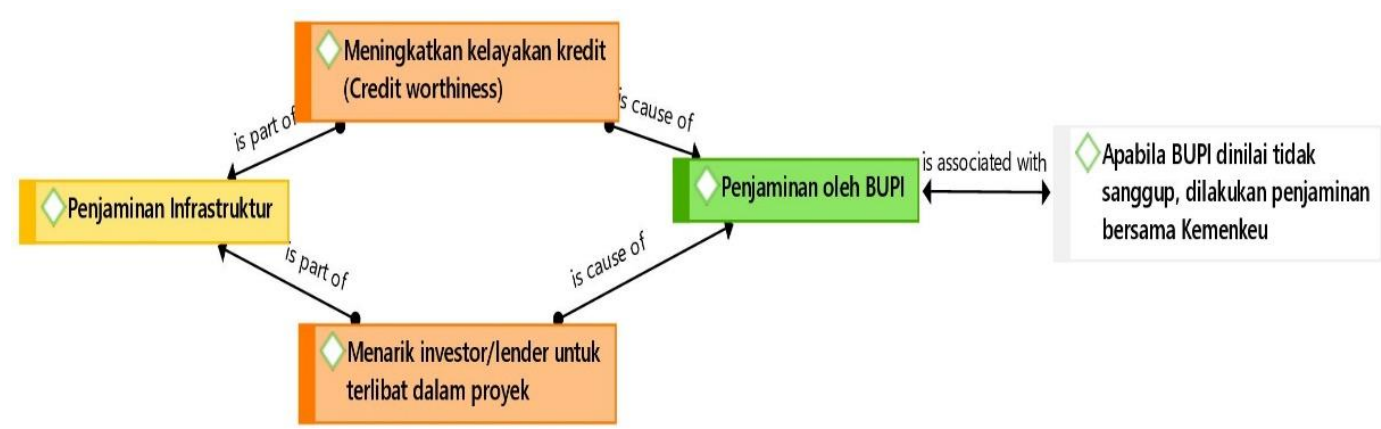

Gambar 4. Analisis Hasil Wawancara (Networking View) 4 (Sumber: data primer yang diolah)

Adapun proses pemberian fasilitas penjaminan berupa penjaminan infrastruktur, diawali dengan kegiatan pengajuan permohonan oleh PJPK kepada BUPI disertai dengan penyerahan persyaratan-persyaratan sesuai tata cara yang telah ditetapkan dalam peraturan mengenai penjaminan infrastruktur. Permohonan penjaminan yang diajukan kepada BUPI memuat deskripsi lengkap tentang rencana penetapan risiko bagi PJPK dan BUP serta dukungan pemerintah yang akan diberikan, termasuk jenis-jenis risiko yang akan dijamin, persentase kewajiban PJPK, dan periode penjaminannya. Atas permohonan penjaminan tersebut, BUPI yang bersangkutan kemudian akan melakukan evaluasi atas aspek-aspek penting dalam pemberian fasilitas penjaminan ini. Apabila hasil evaluasi menunjukkan bahwa permohonan penjaminan yang diajukan dan rancangan PKS yang disusun telah sesuai dengan ketentuan yang berlaku, serta telah memenuhi kelayakan teknis dan finansial, juga dinilai tidak akan mengakibatkan BUPI melampaui batas modalnya, BUPI akan menerima usulan penjaminan tersebut dengan segera menerbitkan pernyataan kesediaannya untuk melakukan penjaminan. Pernyataan kesediaan oleh BUPI inilah nantinya yang kemudian akan dicantumkan oleh Kementerian Perhubungan dalam dokumen pengadaan BUP.

\section{Skema Availability Payment (AP)}

Ketentuan mengenai pelaksanaan skema AP diatur dalam PMK Nomor 260/PMK.08/2016 tentang Tata Cara Pembayaran Ketersediaan Layanan pada Proyek Kerjasama Pemerintah dengan Badan Usaha Dalam Rangka Penyediaan Infrastruktur. AP dapat mulai dilakukan setelah infrastruktur dinyatakan selesai dibangun dan siap memasuki tahap operasi. Dalam rangka menerapkan skema ini, PJPK perlu memperoleh konfirmasi pendahuluan atas penggunaan skema AP atas proyek KPBU yang direncanakan. Setelah memperoleh konfirmasi pendahuluan ini, PJPK selanjutnya akan menyelesaikan dokumen prastudi kelayakan, rancangan perjanjian kerjasama dan komitmen pelaksanaan pembayaran AP proyek KPBU yang bersangkutan. Disamping menyusun dokumendokumen tersebut, PJPK juga diminta untuk melakukan koordinasi terkait hasil penyiapan yang telah dilakukan dengan DJPPR, serta memperoleh surat konfirmasi final penggunaan skema AP melalui Direktorat PDPPI.

Perjanjian kerjasama yang disusun dan disepakati oleh PJPK dan BUP sekurangkurangnya perlu memuat formula perhitungan pembayaran ketersediaan layanan, spesifikasi keluaran, indikator kinerja dan sistem pemantauan untuk dapat menerapkan skema pengembalian investasi AP, sehingga harus diatur secara jelas dan tegas dalam perjanjian kerjasama yang disepakati. Konsep pembayaran AP yang digunakan untuk proyek ini yaitu konsep pembayaran anuitas, karena dilakukan secara tahunan setelah fasilitas infrastruktur tersedia dan beroperasi berdasarkan tingkat ketersediaan layanannya (Darmawan 2018). Menurut DJKA, indikator kinerja yang digunakan dalam kerjasama ini mengacu pada IKU, termasuk didalamnya indikator prasyarat operasional, indikator syarat operasional, dan indikator kinerja layanan. Berdasarkan IKU, PJPK mengukur kisaran besaran AP yang harus dibayarkan kepada BUP dengan mengacu pada tingkat pemenuhan 
persyaratan IKU yang ada. Apabila tidak terpenuhi 100\%, besaran AP yang dibayarkan akan disesuaikan dengan persentase capaian kerja BUP atau tidak dibayarkan secara penuh.

\section{Evaluasi Penyiapan Proyek KPBU KA Makassar-Parepare}

Sebagai penanggungjawab proyek, PJPK tentunya perlu menyusun strategi pelaksanaan KPBU mulai dari tahap perencanaan, persiapan, transaksi hingga pelaksanaannya secara cermat, termasuk strategi dalam mengatasi permasalahan atau kendala proyek yang ada. Namun, permasalahan atau kendala dalam pelaksanaan proyek infrastruktur sangatlah sulit untuk dihindari, baik itu disebabkan oleh faktor internal maupun faktor eksternal. Proyek KPBU KA Makassar-Parepare sendiri juga menghadapi beberapa permasalahan/kendala selama proses penyiapannya. Beberapa permasalahan/kendala yang ditemukan baik oleh PJPK dalam hal ini DJKA dan juga Kementerian Keuangan selaku pihak yang berwenang dan bertanggungjawab dalam pemberian dukungan pemerintah terdiri dari pembebasan lahan, pemahaman PJPK terhadap konsep KPBU, kesiapan SDM dan organisasi.

\section{Isu Pembebasan Lahan}

Berdasarkan hasil wawancara bersama DJKA, DJKA menyebutkan bahwa 70\% dari permasalahan atau kendala yang dihadapi oleh proyek KPBU KA Makassar-Parepare ini adalah masalah penyiapan atau pembebasan lahan yang merupakan salah satu komponen dari dokumen kajian prastudi kelayakan yang dihasilkan. Hal tersebut sebagian besar dikarenakan masih adanya penolakan warga pemilik tanah ataupun adanya nilai ganti untung tanah yang tidak sesuai dengan harapan masyarakat, hingga ada beberapa kasus yang bahkan berlanjut ke proses pengadilan. Tidak hanya itu, tanah yang merupakan Barang Milik Negara (BMN) juga memerlukan proses izin yang panjang, sehingga masalah pengadaan lahan memang dinilai sangat perlu untuk diperhatikan dalam pelaksanaan proyek KPBU.

Menurut Sutantiningrum dan Hatmoko (2019), masalah pembebasan lahan ini bahkan dikategorikan sebagai salah satu dari tiga risiko dengan kesulitan tertinggi pada masa sebelum konstruksi, karena membutuhkan adanya persetujuan dari banyak pihak/stakeholder, serta proses yang lama dan biaya ganti rugi yang mahal. Adapun rencana jalur KA Makassar-Parepare telah disusun dengan baik oleh Kementerian Perhubungan selaku PJPK, begitupula biaya proses pembebasan lahan yang telah dialokasikan dengan menggunakan dana Lembaga Manajemen Aset Negara (LMAN) yang berada di Bagian Anggaran Bendahara Umum Negara (BA BUN) Kementerian Keuangan, sehingga hambatan pembebasan lahan secara keseluruhan sebenarnya terdapat pada proses negosiasi pembebasan lahan itu sendiri dengan beberapa pemilik tanah.

Berdasarkan hasil wawancara bersama Kementerian Keuangan, kegiatan penetapan lokasi untuk proyek kereta api yang akan dibangun mengalami kemunduran waktu yang cukup signifikan dari target awalnya. Hal ini disebabkan oleh adanya masalah pembebasan lahan yang mengharuskan penetapan lokasi mau tidak mau harus diundur. Dengan mengacu pada hal ini, ketersediaan lahan dapat dikatakan memang memainkan peranan yang sangat penting untuk memulai proses konstruksi suatu proyek infrastruktur.

Dalam proses KPBU sendiri, ketika BUP telah berhasil terpilih, BUP perlu mencari pemberi pinjaman (lender) untuk mendukung pembiayaan pelaksanaan proyeknya. Apabila-lender untuk proyek akhirnya ditemukan, selanjutnya perlu dilakukan proses pencairan dana pinjaman terlebih dahulu kepada badan usaha, agar konstruksi proyek dapat segera dimulai. Namun, lender bisa saja ragu untuk memberikan pinjaman kepada BUP, jika lahan untuk pembangunan proyek masih belum tersedia. Hal inilah yang terjadi pada proyek KPBU KA Makassar-Parepare. Badan usaha sudah terpilih, namun masih ada isu pengadaan lahan yang akhirnya membuat proses konstruksi belum dapat segera dimulai. Oleh karena itu, menurut Kementerian Keuangan, untuk menyukseskan 
pelaksanaan proyek KPBU yang telah direncanakan, lahan yang dibutuhkan untuk konstruksi seharusnya sudah dapat tersedia secara bersamaan (parallel) dengan terpilihnya BUP, sehingga konstruksi proyek dapat segera dilaksanakan tanpa harus tertunda lagi karena adanya masalah pembebasan lahan. Hal ini juga sejalan dengan hasil penelitian Nurhayati dan Kusumawati (2020) yang menyatakan bahwa kegiatan pembebasan lahan harus dilaksanakan jauh sebelum suatu proyek infrastruktur diusulkan dalam kegiatan penjajakan minat pasar, dengan tujuan agar BUP terpilih dapat segera melaksanakan tugasnya tanpa harus terkendala lagi dengan masalah pembebasan lahan.

Hal yang dapat dijadikan bahan pembelajaran dari isu pengadaan lahan proyek ini adalah bahwa untuk proyek yang berupa green field atau proyek yang membutuhkan lahan baru sebaiknya diberikan perhatian khusus dalam proses identifikasi kebutuhan atas tanah dan pelaksanaan evaluasi dokumen rencana pengadaan lahannya. Hal ini direspon oleh pemerintah dengan memasukkan dokumen pengadaan lahan sebagai salah satu prasyarat pengajuan PDF. Ketentuan persyaratan ini dapat dilihat pada ketentuan mengenai fasilitas penyiapan dan pendampingan transaksi atau PDF yang baru yaitu PMK Nomor 180 Tahun 2020 tentang Fasilitasi untuk Penyiapan dan Pelaksanaan Transaksi Proyek Kerja Sama Pemerintah dengan Badan Usaha Dalam Penyediaan Infrastruktur. Tak hanya itu, pendampingan dan pemantauan proses pengadaan lahan juga dinilai perlu dilakukan secara intensif, sehingga permasalahan pembebasan lahan dapat segera terselesaikan dengan baik dan tidak lagi menjadi penghambat pelaksanaan proyek.

\section{Isu Pemahaman PJPK Terkait Konsep KPBU}

Sebagai proyek KPBU pertama yang dilaksanakan di Kementerian Perhubungan, masalah pemahaman konsep KPBU pihak-pihak yang terlibat juga turut menjadi salah satu tantangan pelaksanaan proyek. Sebab tanpa pemahaman yang baik terkait KPBU, pelaksanaan proyek kemungkinan besar akan terkendala dan sulit untuk segera terealisasi. Tidak hanya karena konsep KPBU baru pertama kali diterapkan di Kementerian Perhubungan, tetapi juga karena peraturan-peraturan KPBU bersifat dinamis dan terus mengalami perubahan dari tahun ke tahun, sehingga mengharuskan pihak-pihak yang terlibat dalam proyek tidak hanya memahami substansi KPBU secara umum, tetapi juga substansi dari peraturan-peraturan mengenai KPBU yang berlaku.

Dalam rangka mewujudkan kelancaran pelaksanaan proyek KPBU KA MakassarParepare, DJKA selaku pihak yang menerima pendelegasian tugas PJPK dari Kementerian Perhubungan banyak melakukan kegiatan rapat koordinasi dan juga mengikuti kegiatan pelatihan untuk memperdalam pengetahuan mereka terkait KPBU. DJKA juga menyebutkan bahwa dalam pelaksanaan proyek ini, mereka banyak memperoleh bantuan dari PT PII sebagai badan penyiapan, sehingga sangat membantu PJPK dalam mempercepat proses penyiapan pelaksanaan proyek untuk mencapai pemenuhan pembiayaan.

Adapun target yang hendak dicapai melalui tahap penyiapan ini adalah kajian akhir prastudi kelayakan beserta kajian pendukungnya, dokumen AMDAL, perolehan izin terkait proyek berupa penetapan trase dan lokasi, serta surat konfirmasi final penggunaan skema AP. Berdasarkan hasil yang diperoleh, dokumen-dokumen yang disusun oleh Kementerian Perhubungan telah disusun dengan baik sesuai dengan peraturan perundang-undangan yang ada, serta mencakup seluruh aspek terkait pelaksanaan proyek dengan lengkap dan akurat, meskipun dengan adanya kendala awal berupa kurangnya pemahaman PJPK terkait KPBU.

\section{Isu mengenai Pentingnya Pelaksanaan Persiapan yang Baik}

Menurut DJKA, PJPK atau penanggungjawab proyek kerjasama harus bersikap hati-hati dalam pelaksanaan penyiapan proyek yang bersifat brown-field untuk target operasi komersial yang pertama. Dalam hal ini, PJPK perlu memastikan kesiapan organisasi, tidak hanya dari segi alokasi pendanaan, tetapi juga dari segi perencanaan, dokumen desain dan juga lahannya, termasuk kesiapan dari SDM. Pada awalnya, target 
pemenuhan pembiayaan proyek KPBU KA Makassar-Parepare ini adalah Januari 2021, namun dengan adanya amandemen PKS, target pemenuhan pembiayaan proyek diundur hingga April 2021, karena adanya masalah pembebasan lahan dan lender bagi BUP. Penugasan pendampingannya pun diminta oleh PJPK kepada Kementerian Keuangan untuk diperpanjang sesuai target pemenuhan pembiayaan baru yang ditetapkan dalam amandemen PKS. Hal tersebut lah yang menjadi alasan pentingnya pelaksanaan penyiapan proyek yang baik, terutama terkait penanganan masalah pengadaan lahan dan juga lender bagi BUP yang dapat mempengaruhi kelancaran pelaksanaan proyek ini. Apabila masalahmasalah yang ada dapat diatasi dengan baik melalui persiapan yang matang, proyek yang direncanakan juga tentunya akan berjalan sesuai jadwal awalnya dan tidak harus diundur. Oleh karena itu, persiapan yang baik sangatlah penting dan dibutuhkan dalam mengatasi permasalahan yang ada, agar proyek yang direncanakan juga dapat berjalan sesuai targetnya.

\section{SIMPULAN DAN REKOMENDASI SIMPULAN}

Penyiapan proyek KPBU KA Makassar-Parepare secara umum telah dilaksanakan dengan baik sesuai dengan peraturan-peraturan yang mengatur pelaksanaan KPBU dan perkeretaapian, mulai dari penyusunan dokumen prastudi kelayakan, RAB dan KAK, AMDAL, penetapan lokasi proyek, pelaksanaan konsultasi publik dan penjajakan minat pasar, penetapan skema pengembalian investasi BUP, pengajuan konfirmasi penggunaan skema AP, hingga pengajuan pemberian dukungan pemerintah atas proyek KPBU yang meliputi fasilitas penyiapan proyek, penjaminan infrastruktur dan skema pengembalian investasi AP. Namun demikian, beberapa hal dalam penyiapan proyek masih belum dapat terlaksana secara optimal. Salah satunya yaitu terkait penetapan lokasi proyek yang mengalami kemunduran jadwal akibat adanya kendala pada proses pembebasan lahan. Permasalahan lainnya yang turut menjadi tantangan dalam penyelesaian proses penyiapan proyek KPBU KA Makassar-Parepare adalah terkait pemahaman PJPK atas konsep dan prosedur skema KPBU. Pemahaman pihak-pihak yang terlibat ini sangatlah penting untuk diperhatikan oleh PJPK agar proyek KPBU yang telah disiapkan dapat berjalan sesuai dengan targetnya.

\section{REKOMENDASI}

Strategi yang dapat dilakukan PJPK untuk dapat mengatasi permasalahan pembebasan lahan pada proyek KPBU yaitu dengan memastikan bahwa pembebasan lahan sudah dapat diselesaikan saat BUP sudah terpilih. Atau dengan kata lain, proses penyelesaian pembebasan lahan sebaiknya perlu dilakukan lebih awal, jika memang membutuhkan waktu yang cukup lama sebelum BUP terpilih, sehingga tidak akan ada lagi permasalahan terkait lender BUP maupun terhambatnya proses konstruksi akibat masalah pengadaan lahan. Upaya lainnya yang dapat dilakukan oleh PJPK yaitu dengan lebih memperbanyak rapat koordinasi dan juga mengikuti pelatihan-pelatihan, workshop ataupun seminar terkait pelaksanaan KPBU untuk lebih memperkaya wawasan PJPK dalam memahami prosedur pelaksanaan KPBU maupun menyelesaikan permasalahan/kendala yang muncul selama proses pelaksanaannya.

\section{UCAPAN TERIMA KASIH}

Penulis mengucapkan terima kasih kepada pihak Direktorat Jenderal Perkeretaapian (DJKA) Kementerian Perhubungan dan Direktorat Jenderal Pengelolaan Pembiayaan dan Risiko (DJPPR) Kementerian Keuangan yang telah bersedia untuk mengikuti proses wawancara dan membagikan informasi yang dibutuhkan kepada penulis, sehingga tulisan ini dapat terselesaikan dengan baik. 


\section{DAFTAR PUSTAKA}

Adelina, Nenny. 2017. Analisis Faktor-Faktor Resiko Keterlambatan Proyek pada Pembangunan Gedung di Bidang Cipta Karya Dinas Pekerjaan Umum Kabupaten Kutai Timur. Tesis, Malang: Institut Teknik Negeri.

Afriansyah, Ekasatya Aldila. 2018. "Penggunaan Software ATLAS.ti sebagai Alat Bantu Proses Analisis Data Kualitatif." Mosharafa: Jurnal Pendidikan Matematika Vol. 5 (2) 53-63.

Akhmadi, Muhammad Heru. 2017. "Peran Digital Respository dalam Penelitian Bidang Keuangan Negara." Jurnal Manajemen Keuangan Publik Vol. 1 (1) 10-14.

AS, Nur Syam. 2013. "Studi Perencanaan Perkeretaapian di Provinsi Sulawesi Selatan." Jurnal Teknosains Vol. 7 (2) 303-318.

BAPPENAS. 2020. Public Private Partnership: Infrastructure Projects Plan in Indonesia. Jakarta: BAPPENAS.

Darmawan, Arief. 2018. "Mempromosikan Skema KPBU dengan Mekanisme Availability Payment sebagai Alternatif Pembiayaan Pembangunan Sarana-Prasarana (Infrastruktur) Publik di Daerah." Jurnal Ilmu Komunikasi Vol. 4 (1) 1-10.

Fadli, Ardiansyah , and Hilda B Alexander. 2020. Ini Daftar 25 Proyek Infrastruktur KPBU Tahun 2021. December 14. Accessed September 09, 2021. https://www.kompas.com/properti/read/2020/12/14/180929021/ini-daftar-25proyek-infrastruktur-kpbu-tahun-2021.

Irwin, Timonthy C. 2007. Government Guarantees: Allocating and Valuing Risk in Privately Financed Infrastructure Projects. Washington, D.C: World Bank.

Maulana, Mochamad Rifki. 2021. "Pemahaman dan Pembelajaran Tahap Perencanaan dan Penyiapan Pembangunan Infrastruktur di Indonesia Melalui Skema Kerja Sama Pemerintah dan Badan dalam Penyediaan Infrastruktur (KPBU)." Jurnal Ilmu Sosial dan Pendidikan 87-107.

Nurhayati, Yati, Dedes Kusumawati, and Eny Yuliawati. 2020. "Percepatan Implementasi Kerjasama Pemerintah dengan Badan Usaha untuk Pengembangan Infrastruktur Bandar Udara di Indonesia." Warta Ardhia: Jurnal Perhubungan Udara Vol. 46 (1) 26-38.

Palupie, Yudhitya Maharani Ristian, and Hari Agung Yuniarto. 2016. "Alokasi Risiko Proyek Infrastruktur Dengan Skema Kerjasama Pemerintah dan Badan Usaha (KPBU): Suatu Tinjauan Literatur." Seminar Nasional Teknik Industri Universitas Gadjah Mada . Yogyakarta: Prodi Teknik Industri UGM. 96-103.

Peraturan Presiden Republik Indonesia Nomor 38 Tahun 2015 tentang Kerja Sama Pemerintah Dengan Badan Usaha Dalam Penyediaan Infrastruktur.

Peraturan Pemerintah Republik Indonesia Nomor 56 Tahun 2009 tentang Penyelenggaraan Perkeretaapian.

Peraturan Presiden Nomor 78 Tahun 2010 tentang Penjaminan Infrastruktur Dalam Proyek Kerjasama Pemerintah Dengan Badan Usaha Melalui Badan Usaha Penjaminan Infrastruktur.

Peraturan Menteri Perencanaan Pembangunan Nasional/Kepala Bappenas Nomor 4 Tahun 2015 Tentang Tata Cara Pelaksanaan Kerja sama Pemerintah dengan Badan Usaha dalam Penyediaan Infrastruktur. 
Peraturan Menteri Perencanaan Pembangunan Nasional/Kepala Bappenas Nomor 2 Tahun 2020 tentang Perubahan atas Peraturan Menteri Perencanaan Pembangunan Nasional/Kepala Bappenas Nomor 4 Tahun 2015 tentang Tata Cara Pelaksanaan Kerja sama Pemerintah dengan Badan Usaha dalam Penyediaan Infrastruktur.

Peraturan Menteri Keuangan RI Nomor 265/PMK.08/2015 Tentang Fasilitas dalam Rangka Penyiapan dan Pelaksanaan Transaksi Proyek Kerjasama Pemerintah dan Badan Usaha dalam Penyediaan Infrastruktur.

Peraturan Menteri Keuangan RI Nomor 73/PMK.08/2018 tentang Fasilitas untuk Penyiapan dan Pelaksanaan Transaksi Proyek Kerja sama Pemerintah dengan Badan Usaha dalam Penyediaan Infrastruktur.

Peraturan Menteri Keuangan RI Nomor 180/PMK.08/2020 tentang Fasilitas untuk Penyiapan dan Pelaksanaan Transaksi Proyek Kerja sama Pemerintah dengan Badan Usaha dalam Penyediaan Infrastruktur.

Peraturan Menteri Keuangan RI Nomor 260/PMK.08/2016 tentang Tata Cara Pembayaran Ketersediaan Layanan pada Proyek Kerja sama Pemerintah dengan Badan Usaha dalam rangka Penyediaan Infrastruktur.

Peraturan Menteri Perhubungan RI Nomor 78 Tahun 2014 tentang Standar Biaya di Lingkungan Kementerian Perhubungan.

Rahmah, Nidaur. 2019. Pengertian Rencana Anggaran Biaya (RAB), RAP, dan Contoh Format RAB. August 30. Accessed July 21, 2021. https://www.pengadaanbarang.co.id/2019/08/pengertian-rab-rap-dancontohnya.html.

Rahmah, Nidaur. 2019. Pengertian Term of Reference (TOR) atau Kerangka Acuan Kerja (KAK). July 30. Accessed July 21, 2021. https://www.pengadaanbarang.co.id/2019/07/pengertian-term-of-reference-toratau-kak.html.

Razif, Mohammad. 2018. "Peranan Aspek Lingkungan dalam Manajemen Aset Infrastruktur \& Fasilitas." Jurnal Manajemen Aset Infrastruktur dan Fasilitas Vol. 2 (2) 83-93.

Suhendra, Maman. 2017. "Penyediaan Infrastruktur dengan Skema Kerjasama Pemerintah dan Badan Usaha (Public-Private Partnership) di Indonesia." Jurnal Manajemen Keuangan Publik Vol. 1 (1) 41-46.

Sukwika, Tatan. 2018. "Peran Pembangunan Infrastruktur terhadap Ketimpangan Ekonomi Antarwilayah di Indonesia." Jurnal Wilayah dan Lingkungan Vol. 6 (2) 116-117.

Sumardjoko, Imam, dan Muhammad Heru Akhmadi. 2019. "Pengembangan Infrastruktur Konektifitas Sebagai Daya Ungkit Ekonomi Dan Pemangkas Kemiskinan Jawa Timur.” Jurnal Manajemen Keuangan Publik 3 (1): 22-31.

Sutantiningrum, Kartika Hapsari, dan Jati Utomo Dwi Hatmoko. 2019. “Opsi KPBU Proyek SPAM Regional Keburejo Provinsi Jawa Tengah: Pendekatan Manajemen Risiko." Media Komunikasi Teknik Sipil $25 \quad$ (1): 69. doi:10.14710/mkts.v25i1.19450.

Wibowo, Andreas, dan Sri Maria Senjaya. 2020. "Tinjauan Sistematis Kerja Sama Pemerintah Dengan Badan Usaha (Kpbu) Dalam Penyediaan Perumahan Bagi Masyarakat Berpenghasilan Rendah Di Perkotaan.” 